УДК 811.163.41’374:811.161.1’374

$811.163 .41^{\prime} 38$

$811.161 .1^{\prime} 38$

https://doi.org/10.18485/msc50.2021.2.ch58

Богољуб Станковић

\title{
СТИЛИСТИЧКЕ ИНФОРМАЦИЈЕ У РЕЧНИЦИМА СРПСКОГ И РУСКОГ ЈЕЗИКА
}

Предмет наше анализе овом приликом биће информације о стилистичкој обележености савремене српске и руске лексике како у једнојезичним речницима ова два језика, тако и у преводним српско-руским и руско-српским речницима. Мада ћемо се бавити претежно лексикографском стилистиком у једнојезичној српској и руској лексикографији, једнојезична ће нас лексикографија у великој мери интересовати као полазиште и извор стилистичких информација за двојезичну лексикографију. Наше разматрање се заснива углавном на стилистичким информацијама које су дате у Речнику САНУ ${ }^{1}$, Речнику $\mathrm{MC}^{2}$, Речнику Московљевића ${ }^{3}$ у српској лексикографији и Великом ${ }^{4}$ и Малом Академијином речнику ${ }^{5}$ и Речнику Ожегова ${ }^{6}$ у руској лексикографији.

Већ на почетку сучељавања стилистичких информација које дају побројани речници запажају се неподударности у следећим правцима: (1) неподударност информација између једнојезичких речника у једном језику; (2) различит приступ стилистичкој раслојености лексике у речницима једног језика према речницима другог језика; (3) неистоветно и недоследно стилистичко информисање о истоветном лексичком материјалу унутар једног речника.

1 Речник српскохрватског књижевног и народног језика. Књ. I-XIII, Београд, 1959-1988.

2 Речник српскохрватскога књижевног језика. Књ. I-VI, Нови Сад, 1967-1976.

3 М. Московљевић, Речник савременог српскохрватског книжевног језика с језичким саветником, Београд, 1990.

4 Словарь современного русского литературного языка. Т. 1-17, Москва - Ленинград, 1948-1965.

5 Словарь русского языка. Т. 1-4, Москва, 1957-1961.

6 С. И. Ожегов, Словарь русского языка, изд. 1, Москва, 1949; изд. 9 исправленное и дополненное, под ред. Н. Ю. Шведовой, Москва, 1972. 
Кад је реч о неподударности информација између једнојезичких речника било српског, било руског језика, оне најчешће проистичу из два разлога: а) због различитих теоретских полазишта речника; б) због стилистичких промена које су настале у језику за време које дели настанак једног речника према другом или дужине времена током кога се ствара један речник.

А да су речници различито теоретски конципирани и да имају различит приступ стилистичкој маркираности, види се већ из уводних напомена које сваки речник садржи на почетку. Приметно је то чак и код поређења Речника САНУ и Речника МС, који припадају истој лексикографској школи, и нарочито код поређења ова два речника са речником М. Московљевића. Док се у прва два речника у уводним напоменама и списком тзв. техничких скраћеница у већој или мањој мери потенцира стилистичка раслојеност лексике, дотле се у Московљевићевом речнику о томе у предговору ништа не каже, већ се о стилској издиференцираности имплицитно може закључивати на основу списка скраћеница, али је у лексикографској презентацији лексема у корпусу речника стилистички ниво маргинално заступљен.

Једнојезични речници руског језика далеко експлицитније указују на стилску раслојеност лексике у уводним напоменама, мада се и они разликују по подробности и конкретизацији. Најпотпуније је изложена стилистичка компонента у уводним напоменама Малог Академијиног речника ${ }^{7}$ где се лексика стилистички диференцира по следећим основама: а) по припадности лексике различитим слојевима; б) по стилистичкој ограничености употребе речи у књижевном језику; в) по специјалној употреби лексике (терминологија), г) по емоционалној обојености речи; д) по застарелости речи. Терминолошка лексика је у овом речнику издиференцирана по ужим областима (физика, хемија и сл.) и у томе се он разликује од друга два речника руског језика у којима се терминолошки карактер лексема или појединих значења исказује ознаком спеи.

У другом издању Великог Академијиног речника ${ }^{8}$ стилистичка карактеристика лексике даје се са становишта савремене норме, будући да се стилистички статус бројних речи током дугог хронолошког периода мењао. Али је и у другом издању задржан исти систем ознака стилистичких својстава лексике као и у првом. Лексика се стилистички диференцира у оба издања на разговорну, просторечну (народску), архаичну, обласну (дијалекатску), народно-песничку и терминолошку. У другом

\footnotetext{
7 Словарь русского языка, изд. 2, т. 1, Москва, 1981, стр. 9-10.

${ }^{8}$ Словарь современного литературного языка, изд. 2, т. 1, Москва, 1991, стр. 9-11.
} 
издању уведена је и ознака устаревающее („застаревајућа”). Сем побројане диференцијације, указује се и на експресивну компоненту ако је стално присутна у некој лексеми или неком значењу, као што је: иронично, шальво, погрдно и сл.

У уводним напоменама Ожеговљевог речника такође се посвећује пажња стилистици лексике и разматра се у посебном разделу9. На карактеристике употребе речи указује се са становишта функционалне стилистике и становишта историјске перспективе, па се речи диференцирају, с једне стране, на речи књишког стила, високог, официјелног и разговорног стила; затим на народску (просторечну) и дијалекатску (обласну) лексику; и најзад - са становишта емоционалне обојености речи се квалификују ознакама: презриво, неодобравајуће, пренебрегавајуће, шаливо, иронично, погрдно. Терминолошка лексика, тј. лексика која је у научној, техничкој и стручној употреби, обележава се јединствено ознаком спеи., дакле, без диференцирања на научне, техничке и стручне области. Са становишта историјске перспективе разликују се старинске речи, тј. оне које су из терминологије руске прошлости, али се у потребним случајевима употребљавају у савременом руском језику и архаизми, који су изашли или излазе из живе употребе.

Из приказаних неподударности у стилистичком информисању у речницима посебно српског и посебно руског језика назире се и неподударност у приступу и информисању о стилистичкој компоненти између речника српског језика у односу на речнике руског језика.

Различит приступ стилистичкој раслојености једнојезичних речника српског језика у односу на речнике руског језика уочљив је и из саме интерпретације стилистичког нивоа у уводним напоменама. У речницима српског језика о стилистички маркираној лексици је мање речи и без неког посебног издвајања овог нивоа. Тако се, на пример, у Речнику САНУ напоредо говори о дијалектизмима и вулгаризмима, затим о лексици из тајних и уличног језика, али нема диференцијације лексике нити по основу функционалних стилова, нити по основу емоционалне обојености, мада се у списку техничких скраћеница а и у речничкој презентацији указује на емоционалну обојеност. С друге, пак, стране, код презентације стручне терминологије настоји се да се максимално укаже на њену издиференцираност по научним и стручним областима. Сличан однос према стилистичкој маркираности испољен је и у уводним напоменама Речника МС. У оквиру осталих објашњења за употребу речника указује се на стручне термине из науке, уметности, технике, војске, ра-

9 С. И. Ожегов, Словарь русского языка, изд. 9, стр. 12. 
дија, економике, права и др., затим на дијалекатске, покрајинске и локалне речи, архаизме и застареле речи, вулгарне и шатровачке речи.

У уводним напоменама речника руског језика присутан је систематичан и наглашен приступ стилском нивоу лексике, што је, нема сумње, последица и одраз развијености функционалне стилистике као посебне дисциплине руске лингвистичке науке. У сва три речника о стилским карактеристикама говори се издвојено. У Великом Академијином речнику то је у разделу уводних напомена под насловом Семантичка $u$ стилистичка карактеристика речи и илустрачија юихових значеюа и yпотребе, у Малом Академијином речнику под насловом Стилистичке ознаке, а у Речнику Ожегова под насловом Карактеристика употребе речи. И саме формулације наслова под којим се образлаже стилистички ниво указују да и међу речницима руског језика има разлика у приступу стилистици речи, али сви они се у односу на речнике српског језика разликују, поред већ напред реченог, и у следећем: 1. Лексика се диференцира и стилистички маркира по основу припадности функционалним стиловима у више праваца, а најизраженија су супротстављања: а) стилистички неутрална и стилистички обележена лексика; б) лексика писменог и усменог језика у оквиру које се издвајају слојеви: књишка и официјелно-пословна, односно, разговорна и просторечна (народска) лексика. 2. Лексика се диференцира са становишта активне и пасивне употребе у језику. Активна лексика је стилистички неутрална, а пасивна је стилистички обележена било као архаична или лексика која застарева. 3. Лексика се диференцира са становишта експресивности и емоционалне обојености, те се најчешће разликују и обележавају лексеме и значења употребљени шаљиво, презриво, погрдно, иронично и сл. 4. Лексика се диференцира са становишта сфере њене употребе и у првом реду се супротставља општеупотребна и терминолошка лексика. Али се терминолошкој лексици у речницима руског језика приступа по далеко строжим и прецизнијим критеријумима него што је то у речницима српског језика. Терминолошка ознака даје се само уз оне лексеме или значења која се употребљавају само или претежно у одређеним областима науке, технике, уметности и сл. При том у два речника (Великом Академијином и Речнику Ожегова) нема подробног указивања на ужу област употребе, већ се терминолошки карактер истиче ознаком спеи., док је у Малом Академијином речнику проведена и подробнија диференцијација на научне и стручне области (астрономија, физика, ботаника, уметност и сл.). Лексика која је из научних и стручних области нашла широку свакодневну примену у језичком комуницирању и попримила општеупотребну вредност, као и лексика која представља називе животиња, биљака, 
плодова, минерала, метала, апарата, природних појава и сл. даје се у руским речницима без ознаке која би упућивала на њихов терминолошки карактер. И управо оваквим приступом речници руског језика се најбитније разликују од речника српског језика САНУ и МС, који по правилу уз поменуту лексику дају ознаку сфере употребе, или тачније, карактер потицања одређене лексеме из одређене научне и стручне области.

И тако ће, рецимо, лексема ајкула бити праћена ознаком зоол. у речницима САНУ и МС, док се руска еквивалентна лексема акула у сва три анализирана руска речника даје без пратеће ознаке. Лексема аквамарин у поменута два велика речника српског језика дата је са ознаком мин., а у речницима руског језика одговарајућа реч аквамарин даје се без икаквих ознака. Српски речници неједнако поступају са лексемама ампер, уз коју дају ознаку физ., и амперметар, коју дају без ознаке, а руски речници обе еквивалентне лексеме - ампе́р и амперме́тр дају без ознаке. Лексема амплитуда у оба српска речника има ознаку физ., а у руским речницима еквивалентна лексема се различито квалификује: у Великом је без ознаке, у Малом са ознаком физ., а у Речнику Ожегова са ознаком спеu. Српске лексеме амонијак и амонијум праћене су ознаком хем., а еквивалентне руске лексеме аммиа́к и аммоний дате су без ознаке у Великом речнику и Речнику Ожегова, а у Малом речнику аммиа́к је без ознаке, а у речи аммоний издвајају се два значења, при чему се прво маркира ознаком хим. Лексема амеба у речницима САНУ и МС праћена је ознаком зоол., а еквивалентна лексема амёба у сва три руска речника је без икакве ознаке.

Трећи облик неподударности - неистоветно и недоследно стилистичко информисање о истоветном лексичком материјалу унутар једног речника најизраженије је у Речнику Московљевића. Недоследност и несистематичност запажа се већ у списку скраћеница, у коме нема ознаке за физику, али су ту биологија, ботаника, геологија, хемија и сл., а нарочито је видљива код означавања лексикографски обрађеног материјала, тј. у корпусу речника. Ту је уз лексему дифтерија дата ознака мед., али ова ознака изостаје уз највећи број назива болести, па и оних назива који су чешћи у стручним медицинским круговима, него ли у широкој живој употреби (дизентерија, хемороиди, апендицит, апендицитис и сл.); уз лексему амонијак нема ознаке, а уз амонијум дата је ознака хем.

Недоследности и несистематичности у стилистичком информисању има и у речницима САНУ и МС. Није нам циљ да све те недоследности овде наведемо, већ да их само илуструјемо неким примерима. Рекли смо већ да се у ова два речника уз називе биљака и животиња ставља ознака бот., односно зоол. без обзира што су ти називи широко распрострање- 
ни у општем језику, по правилу су из општег језика преузети и као термини употребљени у биолошкој и зоолошкој науци. Овде у ствари поменуте ознаке и не указују на терминолошки карактер лексема, већ на то да су оне из сфере фауне и флоре. Извесна изостављања ових ознака више су резултат техничких пропуста, него ли несистематичности у приступу и обради. Па, ипак, у Речнику МС има и извесног нарушавања система, нарочито код представљања назива за мушки и женски пол појединих животиња. Да се тамо није водило рачуна о систему говори чињеница да су са ознаком зоол. дате лексеме: вепар, вук, говедо, говече, гуска, жаба, зеи, кокош, кон, тисаи, тисица, магаре, магарач, магарица, мачка, мачак, медвед, медведица, патак, патка, свиға итд., док су без ознаке зоол. дате лексеме: бик, во, вучица, гусан, гусак, жабаи, зечии, кобила, крава, крмак, крмача, пастув, петао, теле и др. Да изостављање ознаке зоол. није засновано на упућивању на одредницу помоћу које се реч без ознаке тумачи, говори чињеница о неједнаком поступку са истородним лексемама. Тако се, на пример, уз реч вепар (протумачене као „мужјак свиње”) даје ознака зоол., а уз реч крмак (такође протумачене као „мужјак свиње”) не даје ознака; патак („мужјак патке”) обележава се као зоолошки термин, а гусан, гусак („мужјак гуске”) тог обележја нема: магарица („женка магарца”) носи ознаку зоол., такође и медведииа („женка медведа”), а кобила („женка коња”), крмача („женка свиње”), вучица (женка вука”), зечица („женка зеца”) су без ознаке зоол.; магаре („младунче магарца”), прасе („младо свињче), јагње („младунче од овце”) носе ознаку зоол., а ждребе („младунче коња”), јаре („младунче козе”), пиле („младунче кокоши”), mеле („младунче говечета") су без поменуте ознаке.

И у речницима руског језика евидентно је одсуство унификације стилистичких напомена у оквирима једног истог речника, при том се неуједначеност стилистичког информисања испољава на два начина: (1) лексика истог типа квалификује се различито и (2) стилистички неједнака лексика квалификује се једнако ${ }^{10}$.

Први начин одсуства унификације илустроваћемо примерима из Академијиних речника. У Малом Академијином речнику је, на пример, карболка окарактерисана као разговорна, а хлорка као просторечна лексема; изюмина, картофелина, черносливина маркиране су као разговорне, а брюквина, клюквина, черничина као просторечне. У Великом Академијином речнику горловик је окарактерисано као просторечно, а ушник као разговорно.

${ }^{10}$ Исп.: Г. Н. Скляревская, Заметки о тексикографической стилистике. „Современность и словари”, Ленинград, 1978, „Наука”, стр. 102. 
Примери једнаког квалификовања стилистички неједнаке лексике најчешће имају ознаку спеи., обл., прост. Нема сумње да се ознаком спец. у речницима који користе ову ознаку обједињује разнородна, па чак и стилистички контрастна лексика. И ознака обл. маркира лексику са веома широким дијапазоном употребе: од речи које представљају називе реалија сеоског живота и које немају паралела у књижевном језику, речи представљају локалне дублете у односу на књижевну лексику, до лексике која је неправилна са становишта норме.

Пошто анализирани речници руског језика имају релативно дуг век и постоје у више од једног издања, прерађивани су, исправљани и допуњавани, то је интересантно да се сагледају и разлике у стилистичким информацијама садржаним у различитим издањима једног истог речника. У овим разликама, нема сумње, одржане су објективне развојне промене у стилистичком статусу лексике, настале у периоду који раздваја два издања. О тим разликама може се стећи довољно јасна представа и на основу поређења уводних напомена потоњих (прерађених и допуњених) издања са уводним напоменама првих издања. О тим развојним променама се и директно говори у предговорима потоњих издања.

Тако Н. Шведова као редактор деветог, исправљеног и допуњеног, издања Речника Ожегова (1972. год.) у предговору истиче да су извршене извесне промене и ревизија стилистичких карактеристика речи у правцу веће унификације и приближавања савременој норми. Наглашава да су бројне раније просторечне (народске) речи ушле у говорни језик носилаца књижевног језика, па су и у Речнику ознаке прост. замењене ознаком разг. Пошто је многа терминолошка лексика ушавши у широку употребу променила свој функционално-стилистички карактер, то су и уз многе такве речи ознаке књиж. и спеи. изостављене ${ }^{11}$.

И у предговору другог издања Малог Академијиног речника наглашава се да су унете извесне измене и допуне у стилске карактеристике лексике, нарочито оне која има јасна стилска ограничења, као што је, на пример, традиционално-поетска лексика или официјелно-пословна лексика докумената и сл. ${ }^{12}$ Констатоваћемо ипак да су у другом издању овог речника извршене релативно мале и ограничене измене у стилистичком информисању.

Највеће измене најављене су у другом издању Великог академијиног речника, чији је први том изашао 1991. године, а у предговору се између осталог наглашава и следеће. Задатак новог издања је да се стилистич-

${ }^{11}$ С. И. Ожегов, Словарь русского языка, изд. 9, стр. 7.

12 Словарь русского языка, изд. 2, т. 1, стр. 5. 
ка карактеристика лексике обележи са становишта савремене норме, тј. норме краја XX века. У другом издању задржава се у целости систем стилистичких ознака, али су многе речи, значења, облици и синтагме у другом издању друкчије стилистички окарактерисани у односу на прво, у складу са њиховим измењеним стилистичким статусом. И тако ће у другом издању читав низ речи имати ознаку устар., док су у првом без икакве ознаке. С друге, пак, стране, многе широко распрострањене терминолошке речи у другом издању се презентују без икаквог маркирања, а у првом су дате са ознаком спеи. У другом издању се сем ознаке сnеu., која се примењује углавном за научне термине, уводе додатне напомене које указују на професионализме и социјалне слојеве њихове употребе (у говору морнара, спортиста, ловаца и сл.). ${ }^{13}$

Ако се имају у виду и овако сумарно изложене разлике и неуједначености код пружања стилистичких информација у једнојезичној лексикографији на подручју српскога и рускога језика, јасно је пред коликим се дилемама налази двојезична лексикографија, која по природи ствари израста из једнојезичне и уњој има корене и темеље. Полазећи од стилистичких информација у једнојезичним речницима, двојезични српско-руски и руско-српски речници у великој мери репродукују њихово неуједначено стилистичко информисање о истоветном лексичком материјалу, али у многим случајевима и сами неистоветно и недоследно интерпретирају стилистички истоветне лексеме. Констатовано стање илустроваћемо неким конкретним примерима. У Српско-руском речнику И. Толстоја ${ }^{14}$ означене су као анатомске лексеме: бедро, бедрењача, крајник, рожњача, а без ознаке анат. дате су речи: бут, бутна кост, беоюача, зеница, јетра, слезина и сл. Ознака мед. прати лексеме: ангина, грип, дифтерија, али је лексема туберкулоза без те ознаке. У Руско-српском речнику издавачких кућа МС и „Руског језика” из Москве ${ }^{15}$ дате су ознаком бот. лексеме: вяз, ива, тополь, ясень, а без те ознаке лексеме: берёза, верба; дата је са ознаком зоол. лексема ящерица и без те ознаке лексема змея.

Без намере да овом приликом изложимо подробније своје ставове и погледе на начин стилистичког информисања у двојезичним речницима, нагласићемо само да га у знатној мери треба другачије организовати и реализовати, него што је то у једнојезичним речницима. Стилистичко информисање у двојезичним речницима у великој мери треба да

13 Словарь современного русского литературного языка, стр. 11.

14 И. И. Толстой, Сербскохорватско-русский словарь, изд. З. Москва, 1970.

15 Русско-сербскохорватский словарь (под. ред. Б. Станковича), Москва Нови Сад, 1988. 
је у функцији прецизнијег тумачења и семантизације лексеме полазног језика, па је отуда улога стилистичке напомене да сем указивања на стилистички карактер лексеме и одређивања степена нормативности укаже и на сферу употребе и део реалности којој припада објекат или појава означена тумаченом лексемом. Помоћна функција стилистичких напомена при семантизацији изражена је нарочито код лексема које су пореклом терминолошког карактера или могу имати и тај карактер. Најчешће је употреба или неупотреба ових ознака препуштена субјективном осећању и закључивању двојезичног лексикографа, а преко њега посредно детерминисана тиме колико је преводни еквивалент ближи или даљи језичком знању и осећању потенцијалног корисника. Стога сматрамо да у двојезичним речницима не би било продуктивно ни оптимално ако би се целокупна лексика која представља називе животиња, биљака, хемијских елемената, физичких појава, анатомских делова тела, болести, појава природе и сл. маркирала посебним ознакама како је то у речницима српског језика САНУ и МС, као што са становишта употребне вредности речника не би било оправдано нити апсолутно игнорисање и изостављање посебних ознака, како је то у речницима руског језика. При селективној употреби ових ознака није могуће избећи субјективизам, јер се препушта лексикографу да процењује у којој мери је значење преводног еквивалента познато потенцијалном кориснику, али се за одређене случајеве ипак могу утврдити правила која би тај субјективизам ограничавала. Два су случаја неспорна. 1. За помоћну функцију у семантизацији могле би се користити ознаке конкретнијих дисциплина и сфера као што су анат., бот., војн., зоол., мат., мед., пољопр. и сл. онда кад је преводни еквиваленат лексема страног порекла, те би захтевала од великог броја корисника речника да је додатно тумаче помоћу једнојезичног речника или лексикона страних речи. На пример, код одреднице камелия ознака бот. упућује на сферу објекта који је означен српским еквивалентом камелија и чини излишним да се овај еквивалент ближе објашњава указивањем да је реч о биљци. 2. Условне стилистичке ознаке могу имати помоћну диференцијалну функцију при семантизацији вишезначних лексема чија значења обележавају предмете и појаве из различитих сфера, односно, код лексема које стоје у хомонимском односу. На пример, у одредници српске лексеме лист поред осталих значења без посебних маркирања садржана су и: 1. анат. икра́ 2. зоол. ка́мбала, 3. тех. полотно́ (пилы и т.п.). Руска лексема ячмень има хомонимски карактер - употребљава се за означавање објекта из биљног света и појаве из медицине; у првом случају одредница ће имати ознаку бот., а у другом мед.: ячмен ${ }^{1}$ бот. јечам; ячмень ${ }^{2}$ мед. чмичак, јечменац. 
И најзад, ваљало би се осврнути на проблем успостављања и обележавања стилистичке еквивалентности/нееквивалентности између лексема полазног језика и семантичких преводних еквивалената. Често се у двојезичним речницима стилистички маркирана лексема, услед одсуства лексеме истих стилистичких карактеристика у преводном језику, преводи стилистички неадекватним еквивалентом, а да се на то неподударање не указује. Стилистичка неподударања међу семантичким еквивалентима два језика најчешће се испољавају код лексике која у једном језику има разговорни, народски, дијалекатски карактер или је емоционално обојена. На поменуту неподударност могло би се указивати тако што би се уз стилистички неутралне еквиваленте за стилистички маркиране лексеме та чињеница и саопштавала ознаком неутрално или књижевно или некако слично.

Завршићемо ово сучељавање начина стилистичког информисања у речницима српског и руског језика констатацијом да је оно систематичније, потпуније и актуелније у речницима руског језика, него што је у речницима српског. Одређена достигнућа руске лексикографске стилистике могла би деловати инспиративно и стимулативно код стварања једнотомног речника српског језика сличног Речнику Ожегова за руски језик. Сагледавање стилистичке компоненте постојећих једнојезичних и двојезичних речника српског и руског језика може имати подстицајну и корективну улогу у даљем раду на српско-руским и руско-српским лексикографским остварењима.

\section{Боголюб Станкович}

СТИЛИСТИЧЕСКАЯ ИНФОРМАЦИЯ В СЛОВАРЯХ СЕРБСКОГО И РУССКОГО ЯЗЫКОВ

Резюме

В докладе обсуждаются вопросы лексикографической стилистики, как в толковых словарях русского и сербского языков, так и в переводных сербско-русских и русско-сербских словарях.

Сопоставляя самые известные толковые словари двух языков, автор утверждает и рассматривает несовпадения стилистических информаций в них в следующих направлениях: (1) неодинаковое стилистическое информирование толковых словарей внутри одного языка; (2) неодинаковый подход к лексикографической стилистике в русской лексикографии по отноше- 
нию к сербской; (3) непоследовательность стилистических информаций в рамках одного и того же словаря.

Что касаетсй переводной лексикографии, автор отстаивает мнение, что в двуязычных словарях стилистическое информирование должно иметь, кроме других, и вспомогательную функцию при переводной семантизации лексем. Вследствие этого является необходимость своеобразного стилистического информирования в двуязычных словарях, отличающегося в значительной степени от стилистического информирования в толковых словарях. 